\title{
Das erlösende Wort
}

\author{
James C. Klagge, Blacksburg
}

Wittgenstein was not easily distracted from his work. During the Great War, within two weeks of being stationed at Krakow, he was making philosophical entries in his notebooks. In his coded notebooks, he would comment on the adverse conditions, physical and spiritual. He would also comment on how his philosophical work was progressing.

After almost two months of philosophical entries, Wittgenstein took stock in his coded remarks (Wittgenstein 1991, 32, 17.10.14): "Yesterday worked very hard. The knot is tightening more and more, but I have found no solution [Lösung] ... Will the erlösende thought come to me, will it come??!!" A month later he returns to this concern (44, 21.11.14): "Worked a considerable amount. But still I can never express the one erlösende word. I go round about it and get very close, but still I cannot lay hold of it itself." And the next day: "The erlösende word not expressed. Yesterday it was right on the tip of my tongue. But then it disappears again." But this concern didn't emerge in his philosophical notebooks until 20.1.15 (Wittgenstein 1979a, 39): “The erlösende word-?" and then six months later, more articulately $(54,3.6 .15)$ : “The erlösende word still hasn't yet been spoken."

When Wittgenstein's philosophical notebooks from this period were first published and translated in 1961, Anscombe translated erlösende as "key." There is no reason to suppose she paused over this translation"key" makes sense in the contexts, though it is not a dictionary translation. But the word has resonances in German that are lost with that translation. For instance, when Job says (Job 19:25): "I know that my redeemer liveth", Luther's German Bible renders "redeemer" as Erlöser. Similarly, when the psalmist calls on the Lord (Psalm 19:14) as "my strength, and my redeemer", Luther again has it as Erlöser.

Wittgenstein then drops the word from his work, and reflections on his work, up through the Tractatus. We never hear whether he found "the 
one erlösende word," or even what it could have been. But it seems to have been, for Wittgenstein, something that would constitute a solution [Lösung] to his philosophical problems. We might conjecture that the erlösende word of the Tractatus turned out to be no word at all, but silence-as recommended in proposition 7 ! "Whereof one cannot speak, thereof one must be silent."

When writing to Ludwig von Ficker, a prospective publisher for the Tractatus, Wittgenstein explained (Wittgenstein 1979b, 94-5):

I once wanted to give a few words in the foreword which now actually are not in it, which however, I'll write to you now because they might be a key [Schlüssel] for you: I wanted to write that my work consists of two parts: of the one which is here, and of everything which I have not written. And precisely this second part is the important one. For the Ethical is delimited from within, as it were, by my book; and I'm convinced that, strictly speaking, it can ONLY be delimited in this way. In brief, I think: All of that which many are babbling today, I have defined in my book by remaining silent about it.

Or, one might say, only silence can redeem such babbling.

But upon Wittgenstein's return to philosophical work in 1929, he resumed the search. In a notebook in 1929, he writes (Wittgenstein 199495 v. 1, 176): "The task of philosophy is to find the erlösende word." And then in another notebook from the same year (Wittgenstein 1994-95 v. 2, 68) he repeats this sentence, adding: "The erlösende word is the solution of a philosophical problem." In conversation with Schlick (Waismann 1979, 77, 2.1.30) Wittgenstein comments: "Everything we do consists in trying to find the erlösende word."

On 18.1.31, he elaborated (Wittgenstein 1994-95 v. 3, 156): “The philosopher strives to find the erlösende word, that is, the word that finally permits us to grasp what up until now has intangibly weighed down our consciousness." And then he uses my favorite comparison in all of his writing: "It is as if one had a hair on one's tongue; one feels it but cannot grasp/seize it, and therefore cannot get rid of it." He continues: "The philosopher delivers the word to us with which one/I can express the thing and render it harmless."

Wittgenstein liked these three sentences from 1931 so well that they reappear in a typescript based on the manuscript (TS 211, 158), and are preserved among cuttings taken from that (TS 212, 1115). Then they are 
used in his so-called "Big Typescript" of 1933 (Wittgenstein 1993, 165), where Luckhardt and Aue translate as the "liberating" word. Portions or slight modifications of these sentences appear in typescripts (TS 220, 83, TS 238,11 , and TS 239,84 ) that serve as early drafts of the Investigations, but the phrase does not make it all the way into the Investigations.

Yet I believe the idea retains a role in the Investigations nonetheless. Starting with the opening section of the Investigations (\$1), Wittgenstein states "Explanations come to an end somewhere." This is a truismWittgenstein might have called it a rule of grammar - but it is a truism that, oddly enough, is easy to lose sight of. It's the kind of thing we need to be reminded of (PI §127): "The work of the philosopher consists in assembling reminders for a particular purpose." What is that purpose? Well, we tend to push too far in our desire to understand. Yet not everything can get explained. (Zettel §315): “"Why do you demand explanations? If they are given you, you will once more be facing a terminus. They cannot get you any further than you are at present."'

And the truism holds not just for explanations, but for reasons (PI $\S 326)$ : "the chain of reasons has an end"; justifications (OC §192): "justification comes to an end"; grounds (OC \$204): "giving grounds ... comes to an end"; and definitions (Wittgenstein 1989, 236): "There must be some indefinable things." In each case the press for further ... explanations, reasons, justifications, grounds, definitions leads us ultimately either in a circle or into an infinite regress. That is the truism.

Being truisms, these claims are apt for inclusion in Wittgenstein's philosophical remarks. He holds (PI §599): "Philosophy only states what everyone admits." If we accept these truisms, then we will come to realize that it is untenable to feel that there must be a further ... explanation, reason, justification, ground, definition in every situation. And so we can relax, content that, say, some words cannot be given essentialist definitions. But Wittgenstein's use of the truisms is generally more ambitious than this. For he wants to insist that justification, say, ends not only somewhere, but sooner than we expected.

For Wittgenstein, it is important not only that we stop, but where we stop. In a lecture on 28.4.47, Wittgenstein is reported to have said (Wittgenstein 1989, 90): "It is important in philosophy to know when to 
stop-when not to ask a question." Or, more famously: "The difficulty here is: to stop" ( $\mathrm{Z} \S 314)$.

Stopping at the right place is crucial. The erlösende word is whatever gets us to stop. The temptation to push further "has intangibly weighed down our consciousness." If I can say "Enough!" I "render it harmless." Enough ... explaining, justifying, defining! Wittgenstein writes (MS 115, 30): "Ease of mind begins in philosophy when the erlösende word is found." I have done all I need to do. I can rest content where I am now. I am redeemed, liberated, from misguided temptation.

But, given our temptations, where I reach bedrock is not any kind of truism. And, indeed, Wittgenstein's places to halt can be quite controversial. Wittgenstein's infamous discussion of the seeds $(Z \S \S 608-14$, \& see Klagge, 1999) illustrates this. Wittgenstein's case evokes our feeling that there must be a difference between the seeds, which would explain their producing different plants. "But must there be a physiological explanation here? Why don't we just leave explaining alone?" (Z §614). Well, granted, we could leave explaining alone here-after all, explanations have to come to an end somewhere. But why here? No doubt it is some modern mechanistic scientific urge that drives us beyond this point, but to label it as such is not to undermine it.

Where we are willing to halt the chain is a matter of temperament. That Wittgenstein can rest content with halting the chains sooner than many of us is an important respect in which his $(\mathrm{C} \& \mathrm{~V}, 6-7 / 8-9)$ "spirit is ... different from that of the prevailing European and American civilization." For "the typical western scientist ... will not in any case understand the spirit in which" he writes. His "way of thinking is different from theirs." That Wittgenstein can say "enough!" when he can is an important respect in which his temperament is at odds with ours.

We might say the urge to explain is a natural one, but Wittgenstein sees it as a cultivated urge (or rather, a civilized urge - in a bad sense). But it is clearly this urge that he sets himself against. "People who are constantly asking 'why' are like tourists, who stand in front of a building, reading Baedeker, \& through reading about the history of the building's construction etc etc are prevented from seeing it" (C\&V, 40/46, 3.7.41). "It often happens that we only become aware of the important facts if we suppress the question 'why?'; and then in the course of our investigations 
these facts lead us to an answer" (PI §471). “... attempts at justification need to be rejected" (PI II, 200). This is certainly not a modern approach to things!

Wittgenstein's later mentions of the erlösende word recognize an element of contingency (MS 124, 218; and also MS 179, 3v; both from the mid-1940s): "Whoever does not have these assumptions, for that person it is not the erlösende word." As Wittgenstein put it in a 1938 lecture (Wittgenstein 1993, 411): "Now (today) we have every reason to say there must be a difference [between the seeds]. But we could imagine circumstances where we would break this tradition." The erlösende word does not work in the face of all temptations - in all traditions - and can only be effectively spoken under the right circumstances. It cannot easily be understood by us. Perhaps "only a small circle of people ... to which I turn ... because they form my cultural circle, as it were my fellow countrymen in contrast to the others who are foreign to me" $(\mathrm{C} \& \mathrm{~V}, 10 / 12)$.

While Wittgenstein's utterance of the erlösende word is not easily understood by us, it does fit into a certain trajectory of thought. I would like to conclude by tracing two notable points in this trajectory - texts that raise the issue, and people or characters who have been willing to say "enough" before the rest of us.

\section{Job's Suffering}

The book of $J o b$ in the Hebrew Bible tells the story of a righteous man who suffers greatly, and how he responds. It appears that God is goaded by Satan into allowing Job to be tested, to see if his righteousness is deeply ingrained, or whether it is only a result of his healthy and prosperous life. Thus, his health and prosperity are taken from him to see if he will remain faithful to God, or will instead curse God. The story is very rich with ideas and yet difficult to understand. It is often seen as relevant to the popular question "Why do bad things happen to people?" That seems like a natural question. A traditional answer is that people who suffer must have done something wrong to deserve their suffering.

$J o b$ opens with an omniscient narrator stating that Job (1:1) "was perfect and upright ... and feared God and eschewed evil." Of course, Job and his friends do not occupy an omniscient perspective, and are not privy 
to this information. Nevertheless, even after he suffers the loss of his children, his estate, and his health, Job himself is confident that he is sinless (10:7): "You [God] know very well that I am innocent."

Job is visited by three friends, ostensibly to "offer him sympathy and consolation" (2:11). But the friends, rather than offering compassion, raise the question why Job is suffering, what he has done wrong, and what he can do about it. They are full of advice. Eliphaz (22:4-5): "Do you think [God] is punishing you for your piety and bringing you to justice for that? No, for your great wickedness, more likely, for your unlimited sins." He goes on to conjecture a number of common sins.

Finally (32:1) "These three men stopped arguing with Job, because he was convinced of his uprightness." None of Job's friends can name any wrong-doing of his. Rather, their conception of life is that Job must have done something wrong. Job is suffering while God is just and all-powerful, therefore Job must be sinful. Though Job differs from his friends in maintaining his innocence, he actually agrees with them in supposing that there must be some explanation for his suffering. The difference is that he is ready to blame God. Job is suffering while God is all-powerful and Job is innocent, therefore God must be unjust.

They all suppose that suffering can always be explained. There must be an answer to "why?" A commentator on Job writes (Newsom 1996, 422):

That impulse remains intensely strong in many people. The words that echo in the mind of a person to whom a catastrophe has occurred are frequently 'Why? Why did this happen?' Even those who do not want to claim that 'sin' is always the cause of suffering nevertheless may be heard to say, 'Everything happens for a reason'.

Either Job's guilt, or God's injustice. Or, more commonly, God's mysterious ways - mysterious in the sense that there is a rationale, only not one accessible to us.

So far we have the following parallels to Wittgenstein's seed case: No sins by Job are ever revealed. We respond that there must be a difference between the seeds. Job's friends insist that he must have sinned. Job insists God must be unjust.

Then, finally, God appears on the scene: "Then from the heart of the whirlwind The Lord Yahweh gave Job his answer" (38:1). Essentially his 
response is: Who are you to ask these questions? I'm in charge here! He asks Job a series of rhetorical questions, not meant to be answered. In sum: "Enough!" To which Job replies (40:4) "What can I say?" (42:2, 6): "I know that you are all-powerful ... I retract what I have said."

Perhaps the best way to understand this is to see God as rejecting the search for explanation or justification. Bad things happen-get used to it. Stop trying to explain it; stop asking for a justification. This may leave open the possibility that there is some explanation-perhaps beyond us. But it makes clear that we have no business looking for it. Who are we to ...? Here, God's display of power is the erlösende word. Job's response is silence (40:4-5): "I had better lay my hand over my mouth. I have spoken once, I shall not speak again." And $(42: 3,6)$ : "You have told me about great works that I cannot understand ... I retract what I have said, and repent in dust and ashes."

This certainly upsets our conceptions of justice and of God. But if this upsets our concepts of justice and God, it is high time they were upset! Must there be a moral explanation here? Why don't we just leave explaining alone? Today, in case we actually discovered a case like Job's, we should look frantically for an explanation.-But in other circumstances we might give this up. God, by overawing Job and his friends, is trying to move them to those other circumstances.

If we look at the story wholly from the human point of view of Job and his friends, the "moral" would be that the universe is amoral, even with God in it. This is not a conclusion that would sit easily with many people — suffering as a tragic fact of life. Newsom (625, 630-1) writes:

What Job has been confronted with in the divine speeches will have rendered his old moral categories no longer adequate to his new perception ... They insist that the presence of the chaotic be acknowledged as part of the design of creation, but they never attempt to justify it ... When that happens, it is as though a spell is broken. Job is released from his obsession with justice and can begin the process of living beyond tragedy.

An earlier commentator (Scherer 1954, 1192-3) writes:

Job is no longer asking 'why?' ... There is now for him a place where the problem is not solved, but it is beginning to dissolve ... It does not disturb him any longer at the point where it first disturbed him. He is willing to leave it ... 
Whether this is something one can accept is a matter of temperament.

To complete the comparison then, the voice of God from the whirlwind in $J o b$ occupies a position on the same trajectory that Wittgenstein travels.

\section{Ivan and Suffering}

Unlike the book of $J o b$, with which he was merely familiar, Wittgenstein was certifiably obsessed with Dostoevsky's great novel, The Brothers Karamazov. In 1929 Wittgenstein told Drury (Drury 1984, 86): "When I was a village schoolmaster in Austria after the war I read The Brothers Karamazov over and over again. I read it out loud to the village priest."

In Book 5, Ivan Karamazov meets with his brother Alyosha, a novice at the local monastery and disciple of the Elder Zosima, to talk. In Chapter IV, "Rebellion," the rationalistic Ivan marshals several forceful examples of innocents - mostly children — suffering, and rejects God's world in which such things can happen: "I cannot understand why the world is arranged as it is" (Dostoevsky 1976a, 224). Ivan rejects all possible justifications for such unmerited suffering: retribution, or counterbalancing goods, or some greater harmony. Ivan carries on the case of Job, only with stronger evidence. Ivan is driven by the need to understand, but has no resources to do so.

Dostoevsky made the strongest case he could for Ivan. In a letter he wrote (Dostoevsky 1976b, 758): "Everything my hero says ... is based on reality. All the anecdotes about children took place, existed, were published in the press, and I can cite the places, I invented nothing." Indeed, the head of the Russian Orthodox Church wrote to Dostoevsky (Rosen 1976,884 ) to find out what refutation was possible. (The novel was being published serially.) Dostoevsky insisted: "My hero chooses a theme $I$ consider irrefutable." Or, at any rate, irrefutable from Ivan's rationalistic perspective. There is no rational answer to the question "why?" here.

But Dostoevsky did have a carefully planned response (Dostoevsky 1976b, 761-2): “... will it be answer enough? The more so as it is not a direct point for point answer to the propositions previously expressed ... but an oblique one. Something completely opposite to the world view expressed earlier [by Ivan] appears in this part, but again it appears not point 
by point but so to speak in artistic form." Dostoevsky's answer is Part Six of the novel, "The Russian Monk." Here we are told the life and teachings of Father Zosima. These are presented as a zhitie [a Saint's Life, in Church Slavonic] — a hagiography.

Dostoevsky's strategy is to appeal to the reader's emotions in a way that calms the urge to ask why. Three incidents from Zosima's life before becoming a monk are related, in which, at crucial points, transformations take place that are not explained, but simply presented. Between the first and second story there is a retelling of the Job story (Dostoevsky 1976a, 270-71) that Zosima recalls from childhood. He focuses on the question of how getting new children could be any consolation to Job for the loss of his original children (271): "But how could he love those new ones when those first children are no more, when he has lost them? Remembering them, how could he be fully happy with those new ones, however dear the new ones might be?" No answer, but rather: "But he could, he could. It's the great mystery of human life that old grief passes gradually into quiet tender joy." Of course this does not always happen. Some people are eaten up by old grief - it consumes them: "Why? Why me?" Such people are not wrong to ask these questions, but such questions are not obligatory. Some people have the temperament to let them go.

Ivan will be eaten up, if not ultimately destroyed, by his inability to let go of his questions. The appeal of traditional Orthodox belief will not work with him. He would not understand where Zosima and Alyosha, and for that matter Dostoevsky stand on these issues. The erlösende word does not work for everyone.

Readers of the novel in English or German have little chance of experiencing Dostoevsky's "reply" unaided. But it is possible to imagine parallel experiences that might resonate with English speakers - that might constitute the erlösende word for them. Dostoevsky uses Church Slavonic and other forms of speech reminiscent of religious experiences. One might think of favorite Bible passages rendered in the King James Version, such as the 23rd Psalm, or favorite traditional hymns, such as "Jesus Loves Me," or "Amazing Grace," sung in church as a child. Even if you are not religious, what recollections from childhood can still bring tears to your eyes? The memory of Thanksgiving dinner or Christmas morning with now-gone relatives present. Looking through a box of treasures from your 
childhood. A lullaby your mother sang you. Any experiences that can help you recapture a lost sense of innocence or reverence - these can be the erlösende word that Dostoevsky offers.

Is this a fair "answer"? Should Job have backed down and accepted the new children, as he did? Should Ivan have taken on Alyosha's temperament? Who can say? In a letter to von Ficker (Wittgenstein 1979b, 91, 24.7.15) Wittgenstein uses the term in a more religious sense: "I understand your sad news all too well. You are living, as it were, in the dark, and have not found the erlösende word." Wittgenstein stands in the same trajectory of thought as Dostoevsky and his character Father Zosima. 


\section{Literature}

Dostoevsky, Fyodor 1976a: The Brothers Karamazov: Norton Critical Edition. NY: Norton.

Dostoevsky, Fyodor 1976b: "Dostoevsky's Letters". In: The Brothers Karamazov: Norton Critical Edition. NY: Norton.

Drury, M. 1984: "Some Conversations with Wittgenstein". In: Rhees, R. (ed.): Recollections of Wittgenstein. NY: Oxford University Press.

Klagge, James 1999: "Wittgenstein on Non-Mediative Causality". Journal of the History of Philosophy 37, 653-67.

Newsom, Carol 1996: “Job”. In: The New Interpreter's Bible, v. 4. Nashville: Abingdon Press.

Rosen, Nathan 1976: "Style and Structure in The Brothers Karamazov". In: The Brothers Karamazov: Norton Critical Edition. NY: Norton.

Scherer, Peter 1954 “Job”. In: The Interpreter's Bible, v. 3. Nashville: Abingdon Press.

Waismann, Friedrich 1979: Ludwig Wittgenstein and the Vienna Circle. Oxford: Blackwell.

Wittgenstein, Ludwig 1979a: Notebooks: 1914-1916. $2^{\text {nd }}$ Edition. Chicago: University of Chicago Press.

Wittgenstein, Ludwig 1979b: "Letters to Ludwig von Ficker". In Luckhardt, C.: Wittgenstein: Sources and Perspectives. Ithaca, NY: Cornell University Press, 82-98.

Wittgenstein, Ludwig 1980/1998: Culture and Value. Oxford: Blackwell.

Wittgenstein, Ludwig 1989: Wittgenstein's Lectures on Philosophical Psychology: 1946-47. Chicago: University of Chicago Press.

Wittgenstein, Ludwig 1991: Geheime Tagebücher: 1914-1916. Wien: Verlag Turia \& Kant.

Wittgenstein, Ludwig 1993: Philosophical Occasions: 1912-1951. Indianapolis: Hackett.

Wittgenstein, Ludwig 1994-95: Wiener Ausgabe, Bände 1-3. Wien: Springer Verlag. 
